\title{
Matrix metalloproteinases and genetic mouse models in cancer research: a mini-review
}

\author{
Edyta Wieczorek • Ewa Jablonska • Wojciech Wasowicz • \\ Edyta Reszka
}

Received: 29 July 2014 / Accepted: 15 October 2014 /Published online: 29 October 2014

(C) The Author(s) 2014. This article is published with open access at Springerlink.com

\begin{abstract}
Carcinogenesis is a multistep and also a multifactorial process that involves agents like genetic and environmental factors. Matrix metalloproteinases (MMPs) are major proteolytic enzymes which are involved in cancer cell migration, invasion, and metastasis. Genetic variations in genes encoding the MMPs were shown in human studies to influence cancer risk and phenotypic features of a tumor. The complex role of MMPs seems to be important in the mechanism of carcinogenesis, but it is not well recognized. Rodent studies concentrated particularly on the better understanding of the biological functions of the MMPs and their impact on the pathological process, also through the modification of Mmp genes. This review presents current knowledge and the existing evidence on the importance of selected MMPs in genetic mouse models of cancer and human genetic association studies. Further, this work can be useful for scientists studying the role of the genetic impact of MMPs in carcinogenesis.
\end{abstract}

Keywords MMP · Cancer · Genetic mouse models · Genetic polymorphism $\cdot$ Association studies $\cdot$ Susceptibility

\section{Introduction}

The interactions between tumor cells and their microenvironment reveal the key role of matrix metalloproteinases (MMPs)

\author{
E. Wieczorek $(\triangle) \cdot$ E. Jablonska $\cdot$ W. Wasowicz $\cdot$ E. Reszka \\ Department of Toxicology and Carcinogenesis, Nofer Institute of \\ Occupational Medicine, Lodz, Poland \\ e-mail: edytaw@imp.lodz.pl \\ E. Jablonska \\ e-mail: ewa@imp.lodz.pl \\ W. Wasowicz \\ e-mail: wojciech@imp.lodz.pl \\ E. Reszka \\ e-mail: edyta@imp.lodz.pl
}

during the process of carcinogenesis. Tumor growth and metastasis formation depend on the cell-cell and cell-matrix interactions and also modifications of the tissue through the action of proteolytic enzymes [1-3]. In the early 1980s, Liotta et al. indicated in in vitro studies on mouse cancer cells the importance of these enzymes in the process of metastasis [4]. Members of the MMP family of extracellular proteases include six subgroups which, due to differences in their structure domain, may be involved in a large variety of physiological and pathological processes [5]. The large family of MMPs is composed of 25 endopeptidases in humans and 24 in mice [6, 7]. MMP enzymes play a significant role in cancer invasion, metastasis, and angiogenesis also through their impact on cell behavior such as growth of metastasized tumor cells and increased motility of the epithelial cells [5, 8]. Studies show that the activity of MMP plays a role in extracellular matrix (ECM) protein breakdown, cleavage of cell surface receptors, and release of apoptotic signals, and it is associated with advanced stages and poor clinical outcome in various types of cancer [9-11]. However, MMPs have been reported to be important also at an early stage of tumor progression [12-14]. In 2003, Balbin et al. in his study demonstrated for the first time that $M m p-8$ has a protective role in mouse skin cancer [15]. Nowadays, the reviews focused on the MMP role in cancer metastasis and angiogenesis postulated various opposed effects, such as tumor supporting and inhibiting [16-18]. In this paper, we shall present and discuss current knowledge about MMP studied in mice tumor models and human genetic association studies.

\section{Evaluation of the role of MMP in cancer in genetic mouse models}

The design and conduction of genetic association studies can be challenging and replete with difficulties because of the 
balance of different risks in relation to one another. For all these reasons, the mouse model studies allow us to control or eliminate the effects of genetic and environmental variation and enhance our understanding of cancer disease [19-21]. Despite several limitations resulting from the ethical and technical constraints, the mouse model is a valuable tool because some types of tumors in mice are similar in morphology, histopathology, and molecular characteristics to human tumors [22]. Nowadays, there are many ways to generate genetically engineered mice (GEM) - mice with induced mutations, such as mouse loss of function, i.e., knockdown, knockout, and dominant negative, and mouse gain of function, i.e., transgenic, knockin, and virus-mediated delivery [19, 23]. The Mmp gene knockout mutation also known as Mmp-deficient or null mice is the most common among GEM. Mouse mutants increased our understanding of the molecular and biological functions of protein by engineering constitutive or conditional deletions which delete or invert all or part of a target gene such that the gene is inactivated [24]. Because the loss of function of a gene may be comparable to the effect that occurs for the functional genetic polymorphism in humans, they can be used as a background for showing a relationship between genotype and cancer risk factor.

Genetic mouse models reveal the complexity of MMPs in a variety of biological processes together with normal and pathological tissue conditions, under identical environmental and genetic conditions $[25,26]$. Therefore, they are useful in extending our understanding of cancer pathogenesis. The use of combined mutational mouse models may be exploited to demonstrate interactions between MMPs and other ECM molecules important in understanding the carcinogenic mechanism $[17,27]$. Interactions between MMPs and proteinases of other classes are another important aspect of tumor biology. Understanding these interactions is also necessary for development of effective therapeutic strategies [28]. Additionally, in vitro studies in mice bring us closer to understanding not only the role of MMPs but also the importance of genetic variants of Mmp genes. Thus, genetically modified mouse models allow us to explore the mechanisms underlying the role of various MMPs in cancer, which may be helpful in planning and interpreting future human genetic association studies.

The MMP mRNA expression and activity determined by real-time PCR, zymography, immunoblotting, or immunohistochemistry are recently used as biomarkers of tumor invasion and metastasis in mice, as shown by numerous in vivo studies [29-32].

\section{Genetic polymorphisms in the $M M P s$ as a regulator of MMP gene expression and their impact on cancer risk}

The synthesis of the MMPs is observed under both normal and pathological conditions [33]. Connective tissue cells such as fibroblasts, leukocytes, and macrophages, and tumor stromal elements can synthesize and secrete proMMPs. A wide variety of extracellular factors, including specific tissue MMP inhibitors, cytokines, and environmental growth factors, regulate the synthesis and activity of MMPs in tissue. Expression of $M M P$ genes is under transcriptional regulation by the extracellular factors, transcription factors such as activator protein1, E-twenty-six specific domain, $\mathrm{Sp}-1$, nuclear factor- $\mathrm{kB}$, and promoter TATA box, and also under regulation of genetic polymorphisms [34-36].

The genetic polymorphisms are DNA heritable sequence variants in the genome that may contribute to phenotypic variability, which cause variation in expression, including silencing of genes. Most of the common genetic variants are single nucleotide polymorphisms (SNPs) and deletioninsertion variants (DIVs). These changes probably represent the majority of genetic variability in the human population [37]. A SNP consists in base pair substitution, while a DIV involves nucleotide deletion or insertion. Those allelic variants generated as the result of conversion of a nucleotide to another at a homologous position in the promoter region of the gene may affect gene transcriptional activity. SNPs in the promoter region of $M M P$ may affect transcription through creating a binding site for E-twenty-six or abolishing the binding site for Sp1 [38, 39]. At the same time, SNPs located in exons may lead to a replacement and affect protein function. Another type of genetic polymorphisms is polymorphic microsatellites containing cytosine-adenine dinucleotide repeats and rare copy number variations (CNVs). Taken together, these genetic variabilities have a proven or likely effect on gene expression with a possible impact on the process of tumorigenesis and cancer risk [40].

The functional polymorphisms in the MMPs have been examined in many cancer-associated studies among various populations. Those studies investigated not only the relationship between common genetic polymorphisms and cancer risk but also cancer prognosis, invasiveness, and recurrence [41-43]. The resultant data confirm not only the impact of various genetic polymorphisms in the $M M P s$ on cancer risk but also the lack of association. The results appear to be unclear about whether some common genetic polymorphisms of MMPs may be used as a predictor of cancer risk. Thus, the goals of meta-analysis were to provide an overview of the evidence regarding the $M M P$ genetic polymorphisms and cancer risk [44-48].

To date, genome-wide association studies which used only total cases of cancer versus the control population have not identified loci in MMPs to affect breast or bladder cancer risk $[49,50]$. Also, studies which use mouse mapping quantitative trait loci to predicted human disease $M M P$ genes have not been identified [51, 52]. Both methods have limitations, but use of the GEM might enable better understanding of these results. 


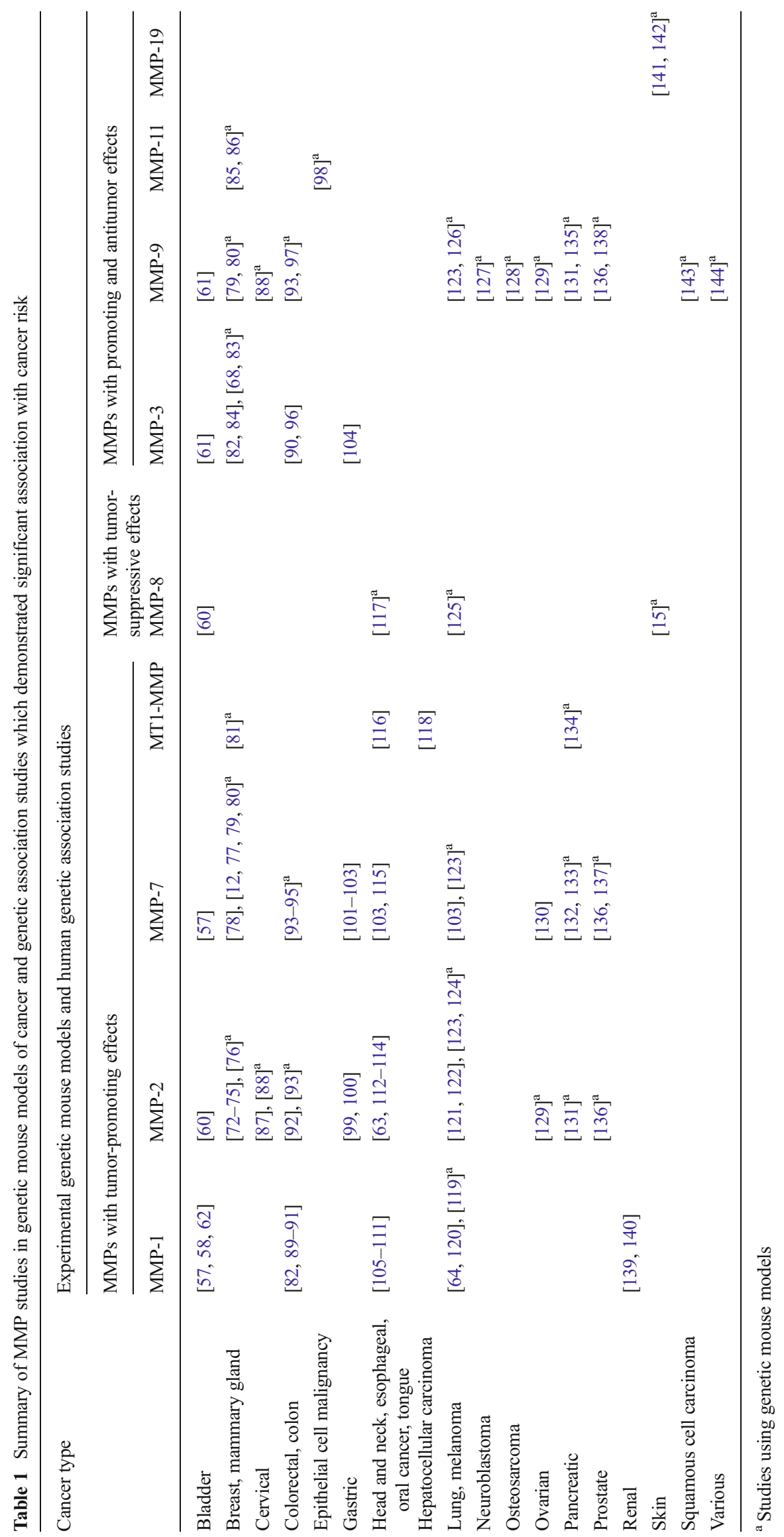




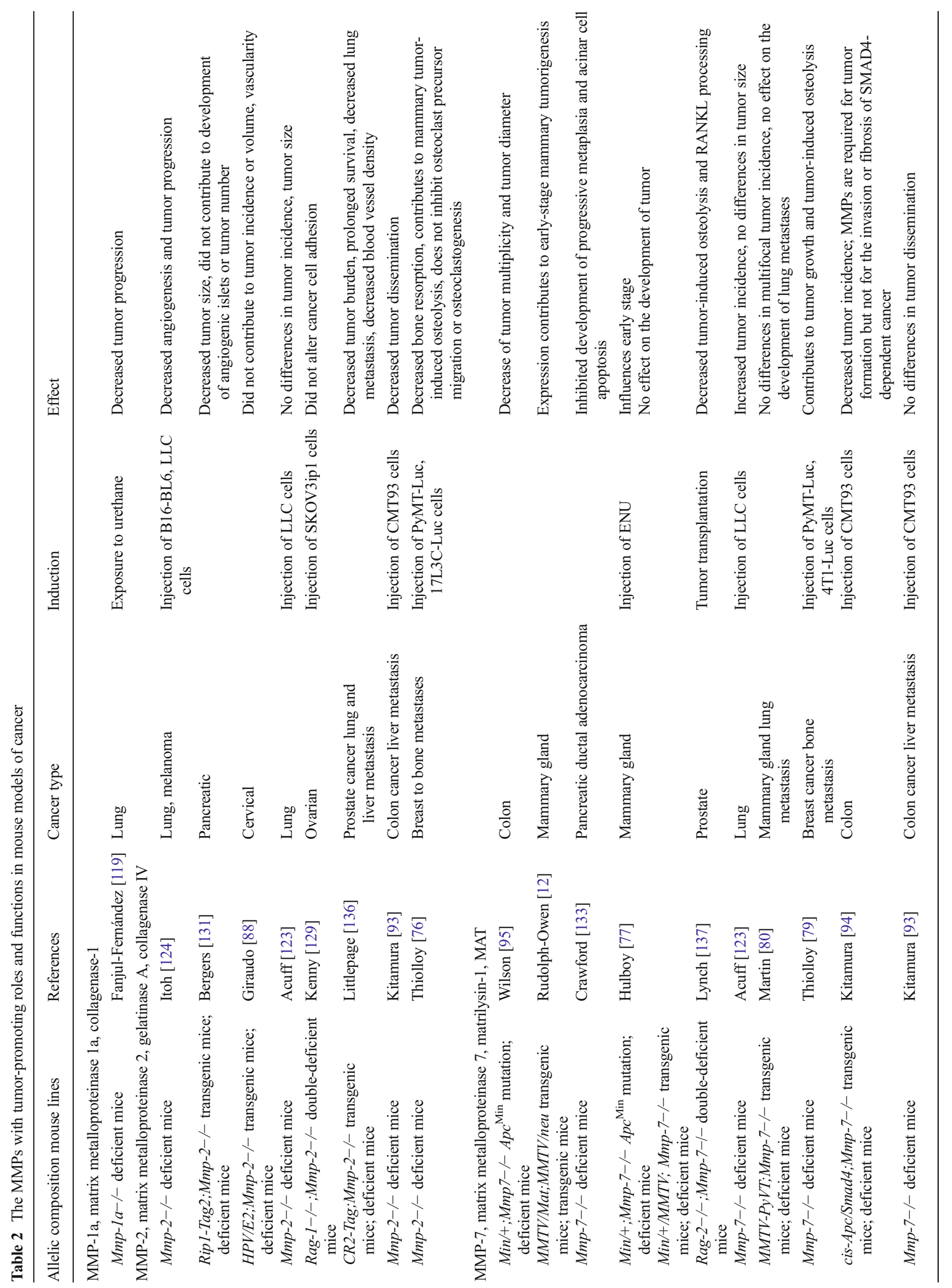




\section{MMPs in carcinogenesis: genetic mouse models} and human genetic association studies

As has been stated by Iyer et al., the creation of Mmp-deficient mice is one of the major MMP milestones [67]. The mouse model has been mainly selected from among the rodent model to study the role of MMPs.

The first cancer study using GEM models in Mmp was conducted in 1995 [68]. In the MMP studies, the most commonly used GEM models are knockout mice, double-deficient mice, but also transgenic mice. Mmp-deficient mice were also evaluated in induced disease such as arthritis, pulmonary fibrosis, and acute hepatitis [27] and in the mouse model of cardiovascular disease [69]. No physiological alterations were observed in the majority of $M m p$-deficient mice, possibly due to the enzymatic compensation and other effects described by Scroyen et al. [70]. However, Mmp-deficient mice demonstrate the individual functions of MMPs [71].

Numerous studies in genetic mouse models of cancer suggest that MMP deficiency may lead to decreased or increased 
tumor progression, incidence, size, and metastasis. In most cases, experimental studies in genetic mouse models of cancer and human association studies confirmed the importance of MMPs (Table 1).

According to the results of the human clinical specimens, genetic mouse models, and human association studies, the role of MMPs in carcinogenesis may be categorized as follows: tumor-promoting, anticancer, and both effects [145].

MMPs with tumor-promoting roles (MMP-1, MMP-2, MMP-7, MMP-14)

Genetic mouse model studies presenting the tumor-promoting role of MMPs in cancer are shown in Table 2. To our knowledge, only one study concerns $M m p$-la-deficient mouse ortholog of human $M M P-1$. In vivo data imply that $M m p-1 a$ has a role in lung tumor progression [119]. Moreover, association studies suggest that functional polymorphism in the $M M P-1$ is associated with risk of colorectal [82, 89-91], bladder [57, 58, 62], renal [139, 140], head and neck [105-111], and lung cancer [64, 120] and risk of lymph node metastases in breast cancer patients [146-148].

Konstantinopoulos et al. wrote in 2008 that MMP-2 may exert cancer-promoting effects [145], and also Mmp-2-deficient mice show antitumor effects on various cancers. The $M M P-2$ genetic polymorphism was associated with risk of breast [72-75], gastric [99, 100], esophageal [63, 112], cervical [87], colorectal [92], lung [121, 122], head and neck [113, 114], and bladder cancer [60].

Mmp-7 (matrilysin-1) has widely been studied in the deficient and transgenic mice; the results demonstrated influences on early-stage mammary cancer $[12,77]$ and decreased tumorigenesis $[94,95,132,137]$. Studies on genetic polymorphism in the MMP-7 show association with risk of bladder [57], breast [78], gastric [101-103], ovarian [130], head and neck [115], esophageal, and lung cancer [103].

MT1-MMP also known as MMP-14 has been described as MMP with anticancer effects [145], but two in vivo studies showed that overexpression of MT1-MMP-induced remodeling of the ECM and mammary gland adenocarcinoma formation [81]; in pancreatic cancer, the MT1-MMP overexpression was seen to affect cancer development [134]. The genetic polymorphism in the MT1-MMP showed association only with susceptibility to hepatocellular carcinoma [118] and oral cancer [116].

Moreover, the results of mouse studies concerning the influence of MMPs on carcinogenesis make it possible to draw some additional conclusions: Mmp-1a modulates immune response to chemical carcinogens by polarization of a Th1/Th2 [119], Mmp-7 mediates tumor-induced osteolysis by solubilization of RANKL [79], and MT1-MMP may be able to increase TGF- $\beta$ signaling [134].

MMPs with tumor-suppressive roles (MMP-8)

The studies confirm that the MMP-8 (collagenase-2) is a metalloproteinase which may exert an anticancer effect (Table 3). Gene knockout mice have been also generated to distinguish the roles of Mmp-8. MMP- 8 may control the invasion potential of tumor cells by modulating cell adhesion [125]. The protective role of MMP-8 has been shown in Mmp8 -deficient mice $[15,117]$. $M M P-8$ genetic polymorphism also showed association with cancer risk, i.e., with low risk of bladder cancer [60] and with lymph node metastases classification in breast cancer patients [149].

MMPs with promoting and antitumor-promoting roles (MMP-3, MMP-9, MMP-11, MMP-19)

Genetic mouse models of cancer presents a dual role of MMPs in carcinogenesis, especially for the MMP-3 and MMP-9 (Table 4). MMP-3 is also known as stromelysin-1 and STR1. WAP-Str1 transgenic mice in mammary cancer can influence the initiation of a tumor; on the other hand, there were no differences in mammary tumor invasion in $M M T V /$ $T G F-\alpha ; \operatorname{Str} 1$ transgenic mice $[68,83]$. Genetic polymorphism in the $M M P-3$ is associated with bladder [61], breast [82, 84], head and neck [104], and colorectal cancer [90, 96].

MMP-9 is probably the most widely studied metalloproteinase. Studies show that Mmp-9 is very important in tumor

Table 3 The MMPs with tumor-suppressive roles and functions in mouse models of cancer

\begin{tabular}{lllll}
\hline $\begin{array}{l}\text { Allelic composition } \\
\text { mouse lines }\end{array}$ & References & Cancer type & Induction & Effect \\
\hline $\begin{array}{l}\text { MMP-8, matrix metalloproteinase 8, collagenase-2 } \\
M m p-8-/- \text { deficient mice }\end{array}$ & Balbín [15] & Skin & Exposure to DMBA, TPA & $\begin{array}{c}\text { Increased the incidence } \\
\text { of tumors } \\
\text { Increased the metastasis } \\
\text { formation }\end{array}$ \\
$M m p-8-/-$ deficient mice & Gutiérrez-Fernández [125] & Lung & Injection of B16F10, LLC cells & $\begin{array}{c}\text { Increased the incidence } \\
\text { of tumors }\end{array}$ \\
\hline
\end{tabular}




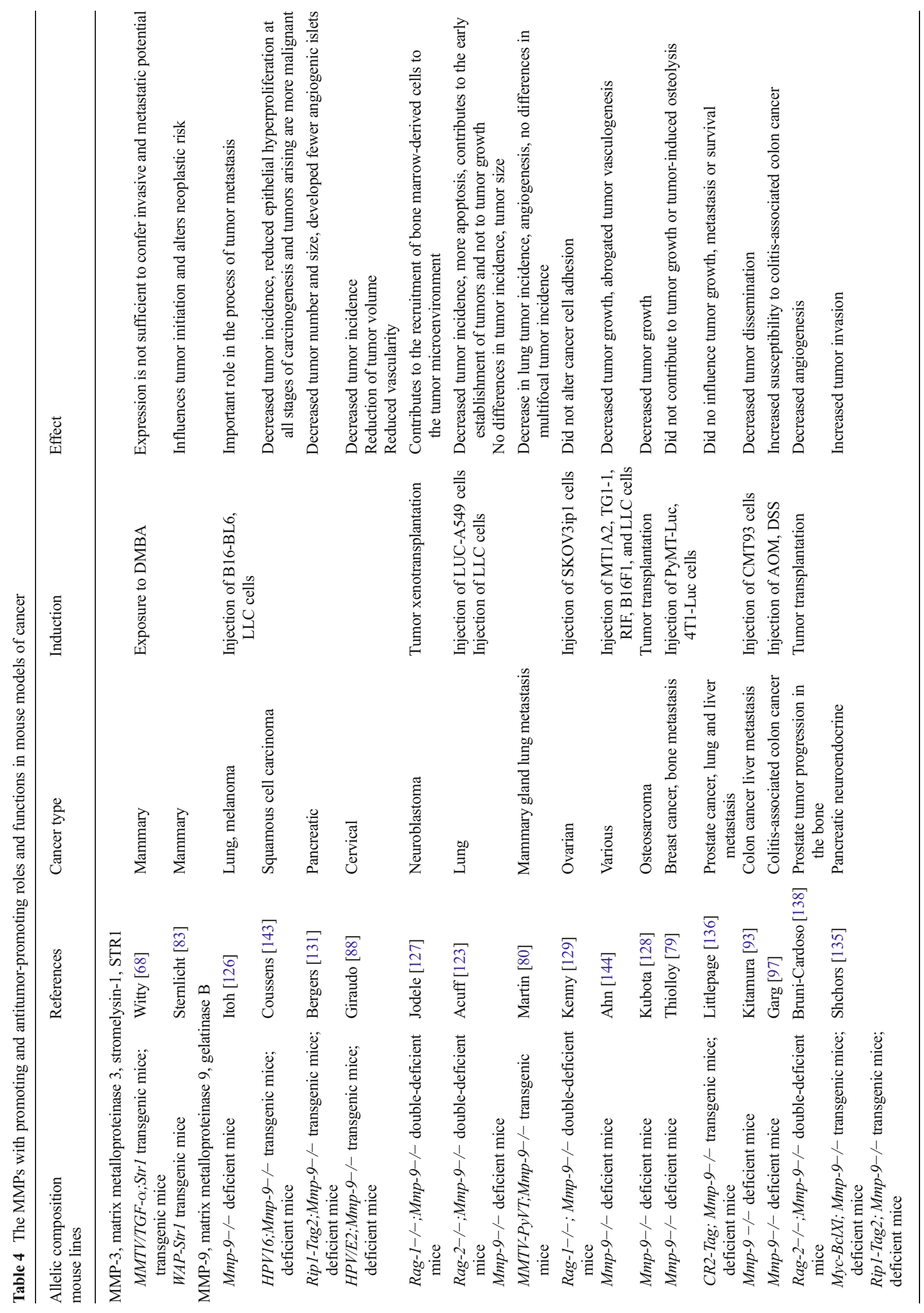


incidence and metastasis $[80,88,93,123,126-128,131,138$, $143,144]$ and may have an anticancer effect in colitisassociated colon cancer and pancreatic neuroendocrine tumor $[97,135]$. Association was found between the MMP-9 polymorphisms and risk of bladder cancer [61], and tumor stage or grade [59]. Additionally, studies of genetic mouse models describe the roles of MMP-9 release VEGFA from the extracellular matrix [131], change Notch-1 activation by module cell cycle inhibitor p21/WAF1/Cip1 and beta-catenin protein activity [97], and participate in keratinocyte differentiation [143]. Expression of MMP-9 was suppressed by zoledronic acid [88].

MMP-11 (stromelisin-3 or ST3) and MMP-19 are important in cancer cell proliferation [150] and demonstrated the opposite roles in studies of genetic mouse models. MMP-11 has influence on adipogenic markers such as peroxisome proliferator-activated receptor and adipocyte protein 2 [85]. The Mmp-19-deficient mouse model not only is considered to negatively regulate the early steps of tumor angiogenesis and invasion but is also thought to be associated with decreased susceptibility to cancer [141, 142]. The association of genetic polymorphisms in the $M M P-11$ and $M M P-19$ with cancer risk has not been investigated; only the results of MMP-19 expression have been described as associated with cancer processes [151-153].

Tumorigenic phenotypes in mice were induced either by chemical induction, transgenic complementation, tumor cell injection, or tumor transplantation. The tumors were chemically induced in mice by exposure to selected carcinogens, like 7,12-dimethylbenzanthracene (DMBA) [68, 98], urethane (ethyl carbamate) [119], 4-nitroquinoline- $N$-oxide (4NQO) [117], methylcholanthrene (MCA) [141], $A^{\prime}$-ethyl- $A^{\prime}$ nitrosourea (ENU) [77], DMBA also with tumor promoter 12-O-tetradecanoylphorbol-13-acetate (TPA) [15], and potent carcinogen azoxymethane (AOM) and dextran sodium sulfate (DSS) [97].

The researchers in in vivo studies of MMPs also used transgenic complementation of $\mathrm{Mmp}$-deficient mice or mutation necessary for cancer. The various transgenic and mutation mouse models of cancer were used: models of pancreatic carcinoma-Rip1-Tag2 [131], Kras [134], Myc-BclXl [135]; model of cervical cancer-HPV/E2 [88]; model of prostate cancer-CR2-Tag [136]; model of colon cancer-cis-Apc/ Smad4 [94]; model of squamous cell carcinoma-HPV16 [143]; model of intestinal neoplasia-Min/Apc [95]; and models of mammary cancer-MMTV [12, 68, 81], MMTV$P y V T$ [80], and MMTV-ras [86]. Also, five studies used immunodeficient mice Rag-1 [127, 129] and Rag-2 [123, 137, 138].

The primary tumors were generated by the injection of tumor cells such as osteolytic luciferase-tagged mammary tumor cell lines (PyMT-Luc and 4T1-Luc, 17L3C-Luc) [76, 79], CMT93 mouse colon cancer cells [93, 94], SKOV3ip1 
cells [129], LUC-A549 cells [123], Lewis lung carcinoma cells (LLC) [123-126, 144], and B16F10 cells [125], B16BL6 cells [126], and others [85, 142, 144]. Lynch et al., Jodele et al., Kubota et al., and Bruni-Cardoso et al. have used tumor transplantation or xenotransplantation into $\mathrm{Mmp}$-deficient mice $[127,128,137,138]$.

Different strain-specific responses occurring in mice with various genetic backgrounds may exert different effects in carcinogenesis. Therefore, only specific selected strains should be used in the experiments [32].

\section{Conclusion}

Already in 1999, Westermarck and Kahari (in review) described in vitro and in vivo studies and reported the evidence for the role and biological mechanisms of the MMPs driving tumor invasion and growth [35]. Currently, the results of the genetic mouse studies demonstrated that deficient mice and transgenic mice models are a successful tool used to identify and explain the functions of MMPs. These studies confirm the importance of differences in genetic pathophysiological mechanisms for distinct $M M P$ genes in various cancer subtypes. In genetic mouse models in which the tumors are induced by chemical carcinogens, cell injection, or tumor implantation, the changing of genetic background may affect tumor susceptibility.

Accumulating evidence suggests that susceptibility to cancer is mediated by genetic and environmental factors and complex gene-environment interactions. Therefore, there is an urgent need for mouse studies in which we may simplify experiments by control of variables such as dietary and lifestyle habits and environmental exposures. It seems that the loss of function of the Mmp gene may be comparable to the effect that occurs for the functional genetic polymorphism in the $M M P$. Therefore, the GEM can be used as a background for showing a relationship between environmental risk factors, genotype, and cancer.

In this review, we summarize and compare the results of genetic mouse models and human association studies, already categorized according to the possible effect of MMPs on the development of cancer. Among the known 25 MMPs, only 9 MMPs have been examined in mouse models: MMP-1, MMP-2, MMP-3, MMP-7, MMP-8, MMP-9, MMP-11, MMP-14, MMP-19. Presented studies confirm that one of the most widely studied of the MMPs is MMP-9. Moreover, only the breast, mammary gland, lung, and pancreatic cancer sites have been extensively studied in mice. Therefore, it seems to be important to focus on the role of various MMPs in other types of cancer, including bladder cancer.

It should be noted that to gain a better understanding of the role of various MMPs in various cancer types, each of the MMPs should be assessed within the same tumor environment. Therefore, more in vivo and in vitro studies are required to allow comparison of the same cancer types and stages. Results from these studies which are based on fundamental knowledge are essential for further investigation in human cancer association studies.

Taken together, genetic in vivo studies complemented by human genetic association studies will extend our knowledge about the genetic predisposition to cancer, by clarifying some of the problems mentioned above: the genetic modifiers and geneenvironment interaction. Future studies will enable the identification of genetic markers essential for early detection of tumors in the future by means of molecular diagnostic procedures.

Acknowledgments This work was supported by Internal Grant IMP 1.7 and the Ministry of Science and Higher Education (2012/05/B/NZ5/ 01406).

\section{Conflicts of interest None}

Open Access This article is distributed under the terms of the Creative Commons Attribution License which permits any use, distribution, and reproduction in any medium, provided the original author(s) and the source are credited.

\section{References}

1. Kessenbrock K, Plaks V, Werb Z. Matrix metalloproteinases: regulators of the tumor microenvironment. Cell. 2010;141:52-67.

2. Fink K, Boratynski J. The role of metalloproteinases in modification of extracellular matrix in invasive tumor growth, metastasis and angiogenesis. Postepy Hig Med Dosw. 2012;66:609-28.

3. Yoon SO, Park SJ, Yun CH, Chung AS. Roles of matrix metalloproteinases in tumor metastasis and angiogenesis. J Biochem Mol Biol. 2003;36:128-37.

4. Liotta LA, Tryggvason K, Garbisa S, Hart I, Foltz CM, Shafie S. Metastatic potential correlates with enzymatic degradation of basement membrane collagen. Nature. 1980;5751:67-8.

5. Klein T, Bischoff R. Physiology and pathophysiology of matrix metalloproteases. Amino Acids. 2011;41:271-90.

6. Page-McCaw A, Ewald AJ, Werb Z. Matrix metalloproteinases and the regulation of tissue remodelling. Nat Rev Mol Cell Biol. 2007;8: 221-33.

7. Overall CM. Molecular determinants of metalloproteinase substrate specificity: matrix metalloproteinase substrate binding domains, modules, and exosites. Mol Biotechnol. 2002;22:51-86.

8. Foda HD, Zucker S. Matrix metalloproteinases in cancer invasion, metastasis and angiogenesis. Drug Discov Today. 2001;6:478-82.

9. Lukaszewicz-Zając M, Mroczko B, Szmitkowski M. Gastric cancer - the role of matrix metalloproteinases in tumor progression. Clin Chim Acta. 2011;412:1725-30.

10. Said AH, Raufman JP, Xie G. The role of matrix metalloproteinases in colorectal cancer. Cancers (Basel). 2014;6:366-75.

11. Werner JA, Rathcke IO, Mandic R. The role of matrix metalloproteinases in squamous cell carcinomas of the head and neck. Clin Exp Metastasis. 2002;19:275-82.

12. Rudolph-Owen LA, Chan R, Muller WJ, Matrisian LM. The matrix metalloproteinase matrilysin influences early-stage mammary tumorigenesis. Cancer Res. 1998;58:5500-6.

13. Stamenkovic I. Matrix metalloproteinases in tumor invasion and metastasis. Semin Cancer Biol. 2000;10:415-33. 
14. Curran S, Murray GI. Matrix metalloproteinases: molecular aspects of their roles in tumour invasion and metastasis. Eur $\mathrm{J}$ Cancer. 2000;36:1621-30.

15. Balbín M, Fueyo A, Tester AM, Pendás AM, Pitiot AS, Astudillo A, et al. Loss of collagenase-2 confers increased skin tumor susceptibility to male mice. Nat Genet. 2003;35:252-7.

16. Decock J, Thirkettle S, Wagstaff L, Edwards DR. Matrix metalloproteinases: protective roles in cancer. J Cell Mol Med. 2011;15: 1254-65.

17. Fingleton B. Matrix metalloproteinases: roles in cancer and metastasis. Front Biosci. 2006;11:479-91.

18. Noël A, Gutiérrez-Fernández A, Sounni NE, Behrendt N, Maquoi E, Lund IK, et al. New and paradoxical roles of matrix metalloproteinases in the tumor microenvironment. Front Pharmacol. 2012;3:140.

19. Cheon DJ, Orsulic S. Mouse models of cancer. Annu Rev Pathol. 2011;6:95-119.

20. Rodríguez D, Morrison CJ, Overall CM. Matrix metalloproteinases: what do they not do? New substrates and biological roles identified by murine models and proteomics. Biochim Biophys Acta. 1803;2010:39-54.

21. Hann B, Balmain A. Building 'validated' mouse models of human cancer. Curr Opin Cell Biol. 2001;13:778-84.

22. Meuwissen R, Berns A. Mouse models for human lung cancer. Genes Dev. 2005;19:643-64.

23. Balmain A. Cancer as a complex genetic trait: tumor susceptibility in humans and mouse models. Cell. 2002;108:145-52.

24. Walrath JC, Hawes JJ, Van Dyke T, Reilly KM. Genetically engineered mouse models in cancer research. Adv Cancer Res. 2010;106:113-64.

25. Bourboulia D, Stetler-Stevenson WG. Matrix metalloproteinases (MMPs) and tissue inhibitors of metalloproteinases (TIMPs): positive and negative regulators in tumor cell adhesion. Semin Cancer Biol. 2010;20:161-8.

26. Becker JC, Houben R, Schrama D, Voigt H, Ugurel S, Reisfeld RA. Mouse models for melanoma: a personal perspective. Exp Dermatol. 2010;19:157-64.

27. Fanjul-Fernández M, Folgueras AR, Cabrera S, López-Otín C. Matrix metalloproteinases: evolution, gene regulation and functional analysis in mouse models. Biochim Biophys Acta. 1803;2010:3-19.

28. Weis SM, Cheresh DA. Tumor angiogenesis: molecular pathways and therapeutic targets. Nat Med. 2011;17:1359-70.

29. Ding L, Zhao Y, Warren CL, Sullivan R, Eliceiri KW, Shull JD. Association of cellular and molecular responses in the rat mammary gland to $17 \beta$-estradiol with susceptibility to mammary cancer. BMC Cancer. 2013;13:573.

30. Son J, Lee JH, Kim HN, Ha H, Lee ZH. cAMP-response-elementbinding protein positively regulates breast cancer metastasis and subsequent bone destruction. Biochem Biophys Res Commun. 2010;398:309-14.

31. Zhang Y, Davis C, Ryan J, Janney C, Peña MM. Development and characterization of a reliable mouse model of colorectal cancer metastasis to the liver. Clin Exp Metastasis. 2013;30:903-18.

32. Akgül B, Pfefferle R, Marcuzzi GP, Zigrino P, Krieg T, Pfister H, et al. Expression of matrix metalloproteinase (MMP)-2, MMP-9, MMP-13, and MT1-MMP in skin tumors of human papillomavirus type 8 transgenic mice. Exp Dermatol. 2006;15:35-42.

33. Nagase $\mathrm{H}$. Activation mechanisms of matrix metalloproteinases. Biol Chem. 1997;378:151-60

34. Clark IM, Swingler TE, Sampieri CL, Edwards DR. The regulation of matrix metalloproteinases and their inhibitors. Int J Biochem Cell Biol. 2008;40:1362-78.

35. Westermarck J, Kähäri VM. Regulation of matrix metalloproteinase expression in tumor invasion. FASEB J. 1999;13:781-92.

36. Chakraborti S, Mandal M, Das S, Mandal A, Chakraborti T. Regulation of matrix metalloproteinases: an overview. Mol Cell Biochem. 2003;253:269-85.
37. Rogers MS, D'Amato RJ. The effect of genetic diversity on angiogenesis. Exp Cell Res. 2006;312:561-74.

38. Price SJ, Greaves DR, Watkins H. Identification of novel, functional genetic variants in the human matrix metalloproteinase-2 gene: role of $\mathrm{Sp} 1$ in allele-specific transcriptional regulation. J Biol Chem. 2001;276:7549-58.

39. Tower GB, Coon CC, Benbow U, Vincenti MP, Brinckerhoff CE. Erk $1 / 2$ differentially regulates the expression from the $1 \mathrm{G} / 2 \mathrm{G}$ single nucleotide polymorphism in the MMP-1 promoter in melanoma cells. Biochim Biophys Acta Mol Basis Dis. 2002;1586:26574 .

40. Loktionov A. Common gene polymorphisms, cancer progression and prognosis. Cancer Lett. 2004;208:1-33.

41. Rothman N, Wacholder S, Caporaso NE, Garcia-Closas M, Buetow $\mathrm{K}$, Fraumeni JF. The use of common genetic polymorphisms to enhance the epidemiologic study of environmental carcinogens. Biochim Biophys Acta. 2001;1471:C1-C10.

42. Wieczorek E, Wasowicz W, Gromadzinska J, Reszka E. Functional polymorphisms in the matrix metalloproteinase genes and their association with bladder cancer risk and recurrence: a mini-review. Int J Urol 2014;17. doi: 10.1111/iju.12431.

43. Wieczorek E, Reszka E, Gromadzinska J, Wasowicz W. Neoplasma. 2012;59:237-47.

44. Peng B, Cao L, Ma X, Wang W, Wang D, Yu L. Meta-analysis of association between matrix metalloproteinases 2, 7 and 9 promoter polymorphisms and cancer risk. Mutagenesis. 2010;25:371-9.

45. Peng B, Cao L, Wang W, Xian L, Jiang D, Zhao J, et al. Polymorphisms in the promoter regions of matrix metalloproteinases 1 and 3 and cancer risk: a meta-analysis of 50 case-control studies. Mutagenesis. 2010;25:41-8.

46. Yang X, Hu JW, Qiu MT, Li M, Yin R, Wang J, et al. Association of matrix metalloproteinase-3-1171(5A $>6 \mathrm{~A})$ polymorphism with cancer risk: a meta-analysis of 41 studies. PLoS One. 2014;9:e87562.

47. Ji SR, Sun JJ, Li XP, Zhang Y, Liu WF. The association of matrix metalloproteinase-1 genetic polymorphism $(-16071 \mathrm{G}>2 \mathrm{G})$ with colorectal cancer: a meta-analysis. Tumor Biol. 2013;34:3801-6.

48. Hu J, Pan J, Luo ZG. MMP1 rs1799750 single nucleotide polymorphism and lung cancer risk: a meta-analysis. Asian Pac J Cancer Prev. 2012;13:5981-4.

49. Figueroa JD, Ye Y, Siddiq A, Garcia-Closas M, Chatterjee N, Prokunina-Olsson L, et al. Genome-wide association study identifies multiple loci associated with bladder cancer risk. Hum Mol Genet. 2014;23:1387-98.

50. Mavaddat N, Antoniou AC, Easton DF, Garcia-Closas M. Genetic susceptibility to breast cancer. Mol Oncol. 2010;4:174-91.

51. Ermann J, Glimcher LH. After GWAS: mice to the rescue? Curr Opin Immunol. 2012;24:564-70.

52. Easton DF, Eeles RA. Genome-wide association studies in cancer Hum Mol Genet. 2008;17:R109-15.

53. Lundberg K, Bengtsson C, Kharlamova N, Reed E, Jiang X, Kallberg $\mathrm{H}$, et al. Genetic and environmental determinants for disease risk in subsets of rheumatoid arthritis defined by the anticitrullinated protein/peptide antibody fine specificity profile. Ann Rheum Dis. 2012;72:652-8.

54. Ghassibe-Sabbagh M, Platt DE, Youhanna S, Abchee AB, Stewart $\mathrm{K}$, Badro DA, et al. Genetic and environmental influences on total plasma homocysteine and its role in coronary artery disease risk. Atherosclerosis. 2012;222:180-6.

55. Sánchez E, de Palma G, Capilla A, Nova E, Pozo T, Castillejo G, et al. Influence of environmental and genetic factors linked to celiac disease risk on infant gut colonization by bacteroides species. Appl Environ Microbiol. 2011;77:5316-23.

56. Lin CW, Yang SF, Chuang CY, Lin HP, Hsin CH. Association of matrix metalloproteinase-11 polymorphisms with susceptibility and clinicopathologic characteristics for oral squamous cell carcinoma. Head Neck. 2014;16. doi: 10.1002/hed.23771. 
57. Srivastava P, Gangwar R, Kapoor R, Mittal RD. Bladder cancer risk associated with genotypic polymorphism of the matrix metalloproteinase- 1 and 7 in North Indian population. Dis Markers. 2010;29:37-46.

58. Tasci AI, Tugcu V, Ozbek E, Ozbay B, Simsek A, Koksal V. A single-nucleotide polymorphism in the matrix metalloproteinase-1 promoter enhances bladder cancer susceptibility. BJU Int. 2008;101:503-7.

59. Kader AK, Shao L, Dinney CP, Schabath MB, Wang Y, Liu J, et al. Matrix metalloproteinase polymorphisms and bladder cancer risk. Cancer Res. 2006;66:11644-8.

60. Srivastava P, Kapoor R, Mittal RD. Association of single nucleotide polymorphisms in promoter of matrix metalloproteinase-2, 8 genes with bladder cancer risk in Northern India. Urol Oncol Semin Orig Investig. 2013;31:247-54.

61. Srivastava P, Mandhani A, Kapoor R, Mittal RD. Role of MMP-3 and MMP-9 and their haplotypes in risk of bladder cancer in North Indian cohort. Ann Surg Oncol. 2010;17:3068-75.

62. Wieczorek E, Reszka E, Jablonowski Z, Jablonska E, Krol MB, Grzegorczyk A, et al. Genetic polymorphisms in matrix metalloproteinases (MMPs) and tissue inhibitors of MPs (TIMPs), and bladder cancer susceptibility. BJU Int. 2013;112:1207-14.

63. Li Y, Sun D, Duan Y, Zhang X, Wang N, Zhou R, et al. Association of functional polymorphisms in MMPs genes with gastric cardia adenocarcinoma and esophageal squamous cell carcinoma in high incidence region of North China. Mol Biol Rep. 2010;37:197-205.

64. Zhang W, Lin H, Zhou Y, Wang Y, Cheng Q. Association of MMP1$1607(1 \mathrm{G}>2 \mathrm{G})$ single nucleotide polymorphism with susceptibility to lung cancer in Northwestern Chinese population of Han nationality. Zhonghua Yi Xue Yi Chuan Xue Za Zhi. 2006;23:313-5.

65. Wang L, Ma YT, Xie X, Yang YN, Fu ZY, Li XM, et al. Interaction between MMP-9 gene polymorphisms and smoking in relation to myocardial infarction in a Uighur population. Clin Appl Thromb Hemost. 2012;18:72-8.

66. Ladiges WC. Mouse models of XRCC1 DNA repair polymorphisms and cancer. Oncogene. 2006;25:1612-9.

67. Iyer RP, Patterson NL, Fields GB, Lindsey ML. The history of matrix metalloproteinases: milestones, myths, and misperceptions. Am J Physiol Heart Circ Physiol. 2012;303:H919-30.

68. Witty JP, Lempka T, Coffey RJ, Matrisian LM. Decreased tumor formation in 7,12-dimethylbenzanthracene-treated stromelysin-1 transgenic mice is associated with alterations in mammary epithelial cell apoptosis. Cancer Res. 1995;55:1401-6.

69. Janssens S, Lijnen HR. What has been learned about the cardiovascular effects of matrix metalloproteinases from mouse models? Cardiovasc Res. 2006;69:585-94.

70. Scroyen I, Hemmeryckx B, Lijnen HR. From mice to men: mouse models in obesity research: what can we learn? Thromb Haemost. 2013;109:1-7.

71. Masson V, de la Ballina LR, Munaut C, Wielockx B, Jost M, Maillard C, et al. Contribution of host MMP-2 and MMP-9 to promote tumor vascularization and invasion of malignant keratinocytes. FASEB J. 2005;19:234-6.

72. Delgado-Enciso I, Cepeda-Lopez FR, Monrroy-Guizar EA, Bautista-Lam JR, Andrade-Soto M, Jonguitud-Olguin G, et al. Matrix metalloproteinase-2 promoter polymorphism is associated with breast cancer in a Mexican population. Gynecol Obstet Investig. 2008;65:68-72.

73. Zhou Y, Yu C, Miao X, Tan W, Liang G, Xiong P, et al. Substantial reduction in risk of breast cancer associated with genetic polymorphisms in the promoters of the matrix metalloproteinase- 2 and tissue inhibitor of metalloproteinase-2 genes. Carcinogenesis. 2004;25: 399-404.

74. Beeghly-Fadiel A, Lu W, Long JR, Shu X, Zheng Y, Cai Q, et al. Matrix metalloproteinase-2 polymorphisms and breast cancer susceptibility. Cancer Epidemiol Biomarkers Prev. 2009;18:1770-6.
75. Roehe AV, Frazzon AP, Agnes G, Damin AP, Hartman AA, Graudenz MS. Detection of polymorphisms in the promoters of matrix metalloproteinases 2 and 9 genes in breast cancer in South Brazil: preliminary results. Breast Cancer Res Treat. 2007;102:1234.

76. Thiolloy S, Edwards JR, Fingleton B, Rifkin DB, Matrisian LM, Lynch CC. An osteoblast-derived proteinase controls tumor cell survival via TGF-beta activation in the bone microenvironment. PLoS One. 2012;7:e29862.

77. Hulboy DL, Gautam S, Fingleton B, Matrisian LM. The influence of matrix metalloproteinase-7 on early mammary tumorigenesis in the multiple intestinal neoplasia mouse. Oncol Rep. 2004;12:13-7.

78. Beeghly-Fadiel A, Long JR, Gao YT, Li C, Qu S, Cai Q, et al. Common MMP-7 polymorphisms and breast cancer susceptibility: a multistage study of association and functionality. Cancer Res. 2008;68:6453-9.

79. Thiolloy S, Halpern J, Holt GE, Schwartz HS, Mundy GR, Matrisian LM, et al. Osteoclast-derived matrix metalloproteinase7, but not matrix metalloproteinase-9, contributes to tumor-induced osteolysis. Cancer Res. 2009;69:6747-55.

80. Martin MD, Carter KJ, Jean-Philippe SR, Chang M, Mobashery S, Thiolloy S, et al. Effect of ablation or inhibition of stromal matrix metalloproteinase- 9 on lung metastasis in a breast cancer model is dependent on genetic background. Cancer Res. 2008;68:6251-9.

81. Ha HY, Moon HB, Nam MS, Lee JW, Ryoo ZY, Lee TH, et al. Overexpression of membrane-type matrix metalloproteinase-1 gene induces mammary gland abnormalities and adenocarcinoma in transgenic mice. Cancer Res. 2001;61:984-90.

82. Biondi ML, Turri O, Leviti S, Seminati R, Cecchini F, Bernini M, et al. MMP1 and MMP3 polymorphisms in promoter regions and cancer. Clin Chem. 2000;46:2023-4.

83. Sternlicht MD, Bissell MJ, Werb Z. The matrix metalloproteinase stromelysin-1 acts as a natural mammary tumor promoter. Oncogene. 2000;19:1102-13.

84. Ghilardi G, Biondi ML, Caputo M, Leviti S, DeMonti M, Guagnellini E, et al. A single nucleotide polymorphism in the matrix metalloproteinase-3 promoter enhances breast cancer susceptibility. Clin Cancer Res. 2002;8:3820-3.

85. Andarawewa KL, Motrescu ER, Chenard MP, Gansmuller A, Stoll I, Tomasetto C, et al. Stromelysin-3 is a potent negative regulator of adipogenesis participating to cancer cell-adipocyte interaction/ crosstalk at the tumor invasive front. Cancer Res. 2005;65:10862-71.

86. Andarawewa KL, Boulay A, Masson R, Mathelin C, Stoll I, Tomasetto $\mathrm{C}$, et al. Dual stromelysin-3 function during natural mouse mammary tumor virus-ras tumor progression. Cancer Res. 2003;63:5844-9.

87. Baltazar-Rodriguez LM, Anaya-Ventura A, Andrade-Soto M, Monrroy-Guizar EA, Bautista-Lam JR, Jonguitud-Olguin G, et al. Polymorphism in the matrix metalloproteinase-2 gene promoter is associated with cervical neoplasm risk in Mexican women. Biochem Genet. 2008;46:137-44.

88. Giraudo E, Inoue M, Hanahan D. An amino-bisphosphonate targets MMP-9-expressing macrophages and angiogenesis to impair cervical carcinogenesis. J Clin Invest. 2004;114:623-33.

89. Ghilardi G, Biondi ML, Mangoni J, Leviti S, DeMonti M, Guagnellini E, et al. Matrix metalloproteinase-1 promoter polymorphism $1 \mathrm{G} / 2 \mathrm{G}$ is correlated with colorectal cancer invasiveness. Clin Cancer Res. 2001;7:2344-6.

90. Hinoda Y, Okayama N, Takano N, Fujimura K, Suehiro Y, Hamanaka $Y$, et al. Association of functional polymorphisms of matrix metalloproteinase (MMP)-1 and MMP-3 genes with colorectal cancer. Int J Cancer. 2002;102:526-9.

91. Woo M, Park K, Nam J, Kim JC. Clinical implications of matrix metalloproteinase-1,-3,-7,-9,-12, and plasminogen activator inhibitor-1 gene polymorphisms in colorectal cancer. J Gastroenterol Hepatol. 2007;22:1064-70. 
92. Xu E, Xia X, Lü B, Xing X, Huang Q, Ma Y, et al. Association of matrix metalloproteinase-2 and -9 promoter polymorphisms with colorectal cancer in Chinese. Mol Carcinog. 2007;46:924-9.

93. Kitamura T, Fujishita T, Loetscher P, Revesz L, Hashida H, KizakaKondoh S, et al. Inactivation of chemokine (C-C motif) receptor 1 (CCR1) suppresses colon cancer liver metastasis by blocking accumulation of immature myeloid cells in a mouse model. Proc Natl Acad Sci U S A. 2010;107:13063-8.

94. Kitamura T, Biyajima K, Aoki M, Oshima M, Taketo MM. Matrix metalloproteinase 7 is required for tumor formation, but dispensable for invasion and fibrosis in SMAD4-deficient intestinal adenocarcinomas. Lab Investig. 2009;89:98-105.

95. Wilson CL, Heppner KJ, Labosky PA, Hogan BL, Matrisian LM. Intestinal tumorigenesis is suppressed in mice lacking the metalloproteinase matrilysin. Proc Natl Acad Sci U S A. 1997;94:1402-7.

96. Lièvre A, Milet J, Carayol J, Le Corre D, Milan C, Pariente A, et al. Genetic polymorphisms of MMP1, MMP3 and MMP7 gene promoter and risk of colorectal adenoma. BMC Cancer. 2006;6:270.

97. Garg P, Sarma D, Jeppsson S, Patel NR, Gewirtz AT, Merlin D, et al. Matrix metalloproteinase-9 functions as a tumor suppressor in colitis-associated cancer. Cancer Res. 2010;70:792-801.

98. Masson R, Lefebvre O, Noël A, Fahime ME, Chenard MP, Wendling $\mathrm{C}$, et al. In vivo evidence that the stromelysin-3 metalloproteinase contributes in a paracrine manner to epithelial cell malignancy. J Cell Biol. 1998;140:1535-41.

99. Miao XP, Yu CY, Tan W, Xiong P, Liang G, Lu WF, et al. A functional polymorphism in the matrix metalloproteinase-2 gene promoter $(-1306 \mathrm{C} / \mathrm{T})$ is associated with risk of development but not metastasis of gastric cardia adenocarcinomal. Cancer Res. 2003;63:3987-90.

100. Zhang XM, Miao XP, Xiong P, Yu CY, Tan W, Qu SN, et al. Association of functional polymorphisms in matrix metalloproteinase-2 (MMP-2) and MMP-9 genes with risk of gastric cancer in a Chinese population. Ai Zheng. 2004;23:1233-7.

101. Li J, Tian M, Zhao A. Polymorphism in the promoter region of the metalloproteinase-7 increases susceptibility and risk of metastasis of gastric adenocarcinoma. Gastroenterology. 2008;134:A603-A603.

102. Sugimoto M, Furuta T, Kodaira C, Nishino M, Yamade M, Ikuma $\mathrm{M}$, et al. Polymorphisms of matrix metalloproteinase-7 and chymase are associated with susceptibility to and progression of gastric cancer in Japan. J Gastroenterol. 2008;43:751-61.

103. Zhang J, Jin X, Fang S, Wang R, Li Y, Wang N, et al. The functional polymorphism in the matrix metalloproteinase-7 promoter increases susceptibility to esophageal squamous cell carcinoma, gastric cardiac adenocarcinoma and non-small cell lung carcinoma. Carcinogenesis. 2005;26:1748-53.

104. Zinzindohoué F, Blons H, Hans S, Loriot MA, Houllier AM, Brasnu $\mathrm{D}$, et al. Single nucleotide polymorphisms in MMP1 and MMP3 gene promoters as risk factor in head and neck squamous cell carcinoma. Anticancer Res. 2004;24:2021-6.

105. O-charoenrat P, Leksrisakul P, Sangruchi S. A functional polymorphism in the matrix metalloproteinase-1 gene promoter is associated with susceptibility and aggressiveness of head and neck cancer. Int J Cancer. 2006;118:2548-53.

106. Hashimoto T, Uchida K, Okayama N, Imate Y, Suehiro Y, Hamanaka Y, et al. Association of matrix metalloproteinase (MMP)-1 promoter polymorphism with head and neck squamous cell carcinoma. Cancer Lett. 2004;211:19-24.

107. McCready J, Broaddus WC, Sykes V, Fillmore HL. Association of a single nucleotide polymorphism in the matrix metalloproteinase-1 promoter with glioblastoma. Int J Cancer. 2005;117:781-5.

108. Cao ZG, Li CZ. A single nucleotide polymorphism in the matrix metalloproteinase-1 promoter enhances oral squamous cell carcinoma susceptibility in a Chinese population. Oral Oncol. 2006;42:32-8.

109. Oezgen AG, Karadeniz M, Erdogan M, Berdeli A. Matrix metalloproteinases (MMP)-1, -2 , and -9 gene polymorphism in papillary thyroid cancers (PTC). Endocrinologist. 2008;18:137-41.
110. Shimizu Y, Kondo S, Shirai A, Furukawa M, Yoshizaki T. A single nucleotide polymorphism in the matrix metalloproteinase-1 and interleukin- 8 gene promoter predicts poor prognosis in tongue cancer. Auris Nasus Larynx. 2008;35:381-9.

111. Lu Z, Cao Y, Wang Y, Zhang Q, Zhang X, Wang S, et al. Polymorphisms in the matrix metalloproteinase-1, 3, and 9 promoters and susceptibility to adult astrocytoma in Northern China. J Neurooncol. 2007;85:65-73.

112. Yu C, Zhou Y, Miao X, Xiong P, Tan W, Lin D. Functional haplotypes in the promoter of matrix metalloproteinase-2 predict risk of the occurrence and metastasis of esophageal cancer. Cancer Res. 2004;64:7622-8.

113. O-Charoenrat $\mathrm{P}$, Khantapura $\mathrm{P}$. The role of genetic polymorphisms in the promoters of the matrix metalloproteinase- 2 and tissue inhibitor of metalloproteinase-2 genes in head and neck cancer. Oral Oncol. 2006;42:257-67.

114. Zhou G, Zhai Y, Cui Y, Qiu W, Yang H, Zhang X, et al. Functional polymorphisms and haplotypes in the promoter of the MMP2 gene are associated with risk of nasopharyngeal carcinoma. Hum Mutat. 2007;28:1091-7.

115. Lu Z, Wang Y, Zhang Q, Zhang X, Wang S, Xie H, et al. Association between the functional polymorphism in the matrix metalloproteinase-7 promoter and susceptibility to adult astrocytoma. Brain Res. 2006;1118:6-12.

116. Weng CJ, Chen MK, Lin CW, Chung TT, Yang SF. Single nucleotide polymorphisms and haplotypes of MMP-14 are associated with the risk and pathological development of oral cancer. Ann Surg Oncol. 2012;19:319-27.

117. Korpi JT, Kervinen V, Mäklin H, Väänänen A, Lahtinen M, Läärä E, et al. Collagenase-2 (matrix metalloproteinase-8) plays a protective role in tongue cancer. Br J Cancer. 2008;98:766-75.

118. Chen TY, Li YC, Liu YF, Tsai CM, Hsieh YH, Lin CW, et al. Role of MMP14 gene polymorphisms in susceptibility and pathological development to hepatocellular carcinoma. Ann Surg Oncol. 2011;18:2348-56.

119. Fanjul-Fernández M, Folgueras AR, Fueyo A, Balbín M, Suárez MF, Fernández-García MS, et al. Matrix metalloproteinase Mmp-1a is dispensable for normal growth and fertility in mice and promotes lung cancer progression by modulating inflammatory responses. J Biol Chem. 2013;288:14647-56.

120. Zhu Y, Spitz MR, Lei L, Mills GB, Wu X. A single nucleotide polymorphism in the matrix metalloproteinase-1 promoter enhances lung cancer susceptibility. Cancer Res. 2001;61:7825-9.

121. Yu C, Pan K, Xing D, Liang G, Tan W, Zhang L, et al. Correlation between a single nucleotide polymorphism in the matrix metalloproteinase- 2 promoter and risk of lung cancer. Cancer Res. 2002;62:6430-3.

122. Zhou Y, Yu C, Miao X, Wang Y, Tan W, Sun T, et al. Functional haplotypes in the promoter of matrix metalloproteinase-2 and lung cancer susceptibility. Carcinogenesis. 2005;26:1117-21.

123. Acuff HB, Carter KJ, Fingleton B, Gorden DL, Matrisian LM. Matrix metalloproteinase- 9 from bone marrow-derived cells contributes to survival but not growth of tumor cells in the lung microenvironment. Cancer Res. 2006;66:259-66.

124. Itoh T, Tanioka M, Yoshida H, Yoshioka T, Nishimoto H, Itohara S. Reduced angiogenesis and tumor progression in gelatinase Adeficient mice. Cancer Res. 1998;58:1048-51.

125. Gutiérrez-Fernández A, Fueyo A, Folgueras AR, Garabaya C, Pennington CJ, Pilgrim S, et al. Matrix metalloproteinase-8 functions as a metastasis suppressor through modulation of tumor cell adhesion and invasion. Cancer Res. 2008;68:2755-63.

126. Itoh T, Tanioka M, Matsuda H, Nishimoto H, Yoshioka T, Suzuki R, et al. Experimental metastasis is suppressed in MMP-9-deficient mice. Clin Exp Metastasis. 1999;17:177-81.

127. Jodele S, Chantrain CF, Blavier L, Lutzko C, Crooks GM, Shimada $\mathrm{H}$, et al. The contribution of bone marrow-derived cells to the tumor 
vasculature in neuroblastoma is matrix metalloproteinase-9 dependent. Cancer Res. 2005;65:3200-8.

128. Kubota Y, Takubo K, Shimizu T, Ohno H, Kishi K, Shibuya M, et al. M-CSF inhibition selectively targets pathological angiogenesis and lymphangiogenesis. J Exp Med. 2009;206:1089-102.

129. Kenny HA, Kaur S, Coussens LM, Lengyel E. The initial steps of ovarian cancer cell metastasis are mediated by MMP-2 cleavage of vitronectin and fibronectin. J Clin Invest. 2008;118:1367-79.

130. Li Y, Jin X, Kang S, Wang Y, Du H, Zhang JH, et al. Polymorphisms in the promoter regions of the matrix metalloproteinases-1, -3, -7, and -9 and the risk of epithelial ovarian cancer in China. Gynecol Oncol. 2006;101:92-6.

131. Bergers G, Brekken R, McMahon G, Vu TH, Itoh T, Tamaki K, et al. Matrix metalloproteinase-9 triggers the angiogenic switch during carcinogenesis. Nat Cell Biol. 2000;2:737-44.

132. Fukuda A, Wang SC, Morris JP, Folias AE, Liou A, Kim GE, et al. Stat3 and MMP7 contribute to pancreatic ductal adenocarcinoma initiation and progression. Cancer Cell. 2011;19:441-55.

133. Crawford HC, Scoggins CR, Washington MK, Matrisian LM, Leach SD. Matrix metalloproteinase-7 is expressed by pancreatic cancer precursors and regulates acinar-to-ductal metaplasia in exocrine pancreas. J Clin Invest. 2002;109:1437-44.

134. Krantz SB, Shields MA, Dangi-Garimella S, Cheon EC, Barron MR, Hwang RF, et al. MT1-MMP cooperates with Kras (G12D) to promote pancreatic fibrosis through increased TGF- $\beta$ signaling. Mol Cancer Res. 2011;9:1294-304.

135. Shchors K, Nozawa H, Xu J, Rostker F, Swigart-Brown L, Evan G, et al. Increased invasiveness of MMP-9-deficient tumors in two mouse models of neuroendocrine tumorigenesis. Oncogene. 2013;32:502-13.

136. Littlepage LE, Sternlicht MD, Rougier N, Phillips J, Gallo E, Yu Y, et al. Matrix metalloproteinases contribute distinct roles in neuroendocrine prostate carcinogenesis, metastasis, and angiogenesis progression. Cancer Res. 2010;70:2224-34.

137. Lynch CC, Hikosaka A, Acuff HB, Martin MD, Kawai N, Singh RK, et al. MMP-7 promotes prostate cancer-induced osteolysis via the solubilization of RANKL. Cancer Cell. 2005;7:485-96.

138. Bruni-Cardoso A, Johnson LC, Vessella RL, Peterson TE, Lynch CC. Osteoclast-derived matrix metalloproteinase- 9 directly affects angiogenesis in the prostate tumor-bone microenvironment. Mol Cancer Res. 2010;8:459-70.

139. Hirata H, Naito K, Yoshihiro S, Matsuyama H, Suehiro Y, Hinoda Y. A single nucleotide polymorphism in the matrix metalloproteinase-1 promoter is associated with conventional renal cell carcinoma. Int J Cancer. 2003;106:372-4.

140. Hirata H, Okayama N, Naito K, Inoue R, Yoshihiro S, Matsuyama $\mathrm{H}$, et al. Association of a haplotype of matrix metalloproteinase (MMP)-1 and MMP-3 polymorphisms with renal cell carcinoma. Carcinogenesis. 2004;25:2379-84.
141. Pendás AM, Folgueras AR, Llano E, Caterina J, Frerard F, Rodríguez F, et al. Diet-induced obesity and reduced skin cancer susceptibility in matrix metalloproteinase 19-deficient mice. Mol Cell Biol. 2004;24:5304-13.

142. Jost M, Folgueras AR, Frérart F, Pendas AM, Blacher S, Houard X, et al. Earlier onset of tumoral angiogenesis in matrix metalloproteinase-19-deficient mice. Cancer Res. 2006;66:5234 41.

143. Coussens LM, Tinkle CL, Hanahan D, Werb Z. MMP-9 supplied by bone marrow-derived cells contributes to skin carcinogenesis. Cell. 2000;103:481-90.

144. Ahn GO, Brown JM. Matrix metalloproteinase-9 is required for tumor vasculogenesis but not for angiogenesis: role of bone marrow-derived myelomonocytic cells. Cancer Cell. 2008;13:193205.

145. Konstantinopoulos PA, Karamouzis MV, Papatsoris AG, Papavassiliou AG. Matrix metalloproteinase inhibitors as anticancer agents. Int J Biochem Cell Biol. 2008;40:1156-68.

146. Przybylowska K, Zielinska J, Zadrozny M, Krawczyk T, Kulig A, Wozniak P, et al. An association between the matrix metalloproteinase 1 promoter gene polymorphism and lymph node metastasis in breast cancer. J Exp Clin Cancer Res. 2004;23:121-5.

147. Przybylowska K, Kluczna A, Zadrozny M, Krawczyk T, Kulig A, Rykala J, et al. Polymorphisms of the promoter regions of matrix metalloproteinases genes MMP-1 and MMP-9 in breast cancer. Breast Cancer Res Treat. 2006;95:65-72.

148. Hughes S, Agbaje O, Bowen RL, Holliday DL, Shaw JA, Duffy S, et al. Matrix metalloproteinase single-nucleotide polymorphisms and haplotypes predict breast cancer progression. Clin Cancer Res. 2007;13:6673-80.

149. Decock J, Long JR, Laxton RC, Shu XO, Hodgkinson C, Hendrickx $\mathrm{W}$, et al. Association of matrix metalloproteinase- 8 gene variation with breast cancer prognosis. Cancer Res. 2007;67:10214-21.

150. Gialeli C, Theocharis AD, Karamanos NK. Roles of matrix metalloproteinases in cancer progression and their pharmacological targeting. FEBS J. 2011;278:16-27.

151. Stojic J, Hagemann C, Haas S, Herbold C, Kuehnel S, Gerngras S, et al. Expression of matrix metalloproteinases MMP-1, MMP-11 and MMP-19 is correlated with the WHO-grading of human malignant gliomas. Neurosci Res. 2008;60:40-9.

152. Impola U, Jeskanen L, Ravanti L, Syrjänen S, Baldursson B, Kähäri VM, et al. Expression of matrix metalloproteinase (MMP)-7 and MMP-13 and loss of MMP-19 and p16 are associated with malignant progression in chronic wounds. Br J Dermatol. 2005;152:720 6.

153. Bister VO, Salmela MT, Karjalainen-Lindsberg ML, Uria J, Lohi J, Puolakkainen P, et al. Differential expression of three matrix metalloproteinases, MMP-19, MMP-26, and MMP-28, in normal and inflamed intestine and colon cancer. Dig Dis Sci. 2004;49:653-61. 